Review

\title{
On the Questionable Appeal of Glossy/Shiny Food Packaging
}

\author{
Charles Spence (D)
}

check for

updates

Citation: Spence, C. On the Questionable Appeal of Glossy/Shiny Food Packaging. Foods 2021, 10, 959. https://doi.org/10.3390/foods1005 0959

Academic Editor: Anastasia Badeka

Received: 6 April 2021

Accepted: 26 April 2021

Published: 28 April 2021

Publisher's Note: MDPI stays neutral with regard to jurisdictional claims in published maps and institutional affiliations.

Copyright: (C) 2021 by the author. Licensee MDPI, Basel, Switzerland. This article is an open access article distributed under the terms and conditions of the Creative Commons Attribution (CC BY) license (https:/ / creativecommons.org/licenses/by/ $4.0 /)$.
Department of Experimental Psychology, Anna Watts Building, University of Oxford, Oxford OX2 6BW, UK; charles.spence@psy.ox.ac.uk

\begin{abstract}
Those stimuli that have a shiny/glossy visual appearance are typically rated as both attractive and attention capturing. Indeed, for millennia, shiny precious metals and glossy lacquerware have been used to enhance the presentation, and thus the perception, of food and drink. As such, one might have expected that adding a shiny/glossy appearance/finish to the outer packaging of food and beverage products would also be desirable. However, the latest research appears to show that many consumers have internalised an association between glossy packaging and greasy (or unhealthy) food products, while matte packaging tends to be associated with those foods that are more natural instead. Furthermore, it turns out that many consumers do not necessarily appreciate the attempt to capture their attention that glossy packaging so often affords. At the same time, it is important to recognise that somewhat different associations may apply in the case of inner versus outer food and beverage packaging. Shiny metallic (inner) packaging may well prime (rightly or wrongly) concerns about sustainability amongst consumers. Given the research that has been published in recent years, food and beverage manufacturers/marketers should think very carefully about whether or not to introduce such shiny/glossy finishes to their packaging.
\end{abstract}

Keywords: packaging; glossy; shiny; material properties; inner; outer; learned associations; evolutionary explanations

\section{Introduction}

For millennia, people have found shiny/glossy (the difference between glossy and shiny surfaces is that glossy is more the property of a surface, whereas shiny is more the property of reflecting an external light source) surfaces to be visually appealing in the context of food service (e.g., [1-3]; [4] p. 19), often transferring positive attributes to the experience of the food itself ([5] pp. 159-160; [6,7]). (As the Roman gourmand Apicius suggested in the first century AD: "an expensive silver platter would enhance the appearance of this dish materially" when referring to the plating of his Apician Dish (number 141; [8] p. 103).) What is more, Western cutlery made from shiny precious metals, such as gold and platinum has also held a certain appeal amongst the wealthy over the centuries ([9] p. 106; [10] p. 190). At the same time, it is worth noting that while aluminium foil was considered a futuristic material when it was first introduced back in the 1920s (e.g., by the Italian Futurists; see [11]), nowadays, like stainless steel, it has become an ubiquitous material, hence largely devoid of any symbolic meaning [12].

A shiny metallic appearance can help to set positively-valenced expectations [13] that then carry over to influence the tasting experience. For instance, metallic cups have been shown to evoke positive associations (i.e., of elegance), which can then give rise to enhanced tasting experiences $[6,14-16]$. At the same time, and as we have just seen, the symbolic meaning of different shiny metallic surfaces, such as that represented by aluminium foil, have undoubtedly changed over the decades ([11]; see also [17]). Furthermore, a good part of the appeal of glistening/glossy surfaces may traditionally have been linked to the dim indoor illumination (such as candlelight), as stressed by Tanizaki [3] in his extended aesthetics essay In Praise of Shadows. In the brightly-illuminated modern interior, however, such shiny precious metals can all too easily appear garish. 
Going beyond the serviceware itself, at times, people have also been intrigued by the idea of eating foods that appear metallic (i.e., as when foods were occasionally covered in gold leaf for the lucky few who could afford it in Medieval England, see [4]) or iridescent (such as the surmullet fish in ancient Rome; see Andrews [18]). Many adverts for luxury items including alcoholic beverages use extrinsic attributes, such as gold and shininess, in order to try to convey prestige and style [19]. Note here also how there are likely to be cross-cultural differences in the meaning of food and beverage packaging appearance cues (such as shiny or glossy), as has previously been shown in the case of the meaning of packaging colour $[20,21]$. For instance, when used in outer packaging, a silver appearance is associated with the packaging of dairy products in the U.S., while being associated with fresh seafood in Norway [22,23]. Gold foil makes an occasional (both distinctive and eye-catching) appearance in the covering of the Lindt Goldhaser Easter chocolate bunny ([24] p. 84). That said, it has been argued that gold is not widely associated amongst customers with any particular product category or brand [25], excepting perhaps Nescafe's Gold Blend instant coffee, Starbucks Gold Label, and the Lindt gold bunny. Meanwhile, giving a wine label a metallic visual appearance property can be used to effectively convey luxury/elegance [26], as has been successfully achieved in the world of heraldic-looking wine labels [27,28].

While shiny metallic and glossy surfaces/materials have long held an appeal to consumers, the question to be addressed in this review is whether the same is still true currently when it comes to the packaging of food and beverage products. However, before getting to that intriguing question, it is first worth summarising the literature concerning why exactly it should be that we find glossy and shiny surfaces attractive to begin with.

\section{Why, Exactly, Are Glossy/Shiny Surfaces So Appealing?}

Those stimuli that have a shiny/glossy visual appearance are typically rated as both attractive and attention capturing (e.g., [29-31]). Perhaps unsurprisingly, researchers have demonstrated that people prefer shiny to tarnished metal objects [32]. (According to the research, and contrary to European folklore, magpies are not attracted to shiny objects [33]). In the latter study, people were shown to prefer shiny silver coins over dull ones and mirror-polished copper cylinders over cylinders that had a brushed or dull surface. Glossy products are often associated with luxury [16]. According to one popular suggestion, humans are drawn to glossy surfaces as that may, evolutionarily speaking, have provided a robust cue as to the presence of fresh water, which would have been necessary for human survival (see [34-37] on visual cues to the perception of wetness). At the same time, it should also be noted that elsewhere in the literature, researchers have drawn attention to the association that exists between glossiness and freshness (e.g., of fish eyes, while glossy implying the wetness of the surface [38], not to mention fruits and vegetables [39,40]. Furthermore, in the context of foods, energy-dense fats often present a glossy visual appearance. Relevant here, a separate line of empirical research has demonstrated the attention-capturing properties of high-fat (i.e., energy dense) food images [41-43]. Hence, this might be taken to provide another alternative (non-exclusive) evolutionary explanation as to why glossy stimuli should be rated as so attractive (see also [44,45]).

People have been shown to find glossy shiny landscape photos more attractive than flat matte ones [46]. The researchers in the latter study manipulated the glossiness of paper on a between-participants basis while holding constant weight, colour quality, and resolution. One hundred participants viewed a number of landscape photos on either high-gloss photo paper or on identical paper where a flat, matte spray finish had been applied instead. A non-significant trend toward glossiness being rated as more attractive was observed. However, it turned out that in those individuals for whom the aesthetic appreciation characteristic of the 'openness to experience' trait (as assessed by means of a separate questionnaire; see [47]) was low, the glossy images were strongly preferred over the matte photos (thus replicating previous findings in the literature). By contrast, in those 
for whom aesthetic appreciation was high, there was no significant difference between image finishes.

There has been much research into the visual rendering of material qualities such as glossy [48-54], matte [55], metallic [12], translucent (e.g., [56,57]), shiny and iridescent (e.g., [30,58]). Furthermore, there is much interest in the digital rendering of such appealing visual appearance properties, based on the underlying image statistics that are related to specific perceptual judgments (e.g., see [59-61]; though see also [62]). There is also growing interest in understanding the neural mechanisms underpinning the various aspects of material perception (see [30] for a review).

How we interact with an object can also be influenced by whether or not it has been given a shiny/glossy surface appearance $[16,63]$. At the same time, physically touching surfaces/objects that are slippery has also been shown to enhance perceived gloss $[64,65]$. Meanwhile, Decré and Cloonan [66] have demonstrated that glossy (vs. matte) packaging influences the haptic perception of the roughness, thickness, and lightness of product packaging (see also $[67,68]$ ), which may, in turn, influence judgments of product quality/sophistication. In particular, products with a matte surface were rated as rougher, thicker, and heavier than those with a gloss surface (as assessed by three seven-point semantic differential scales).

One intriguing low-level stimulus feature that will be focused on here is glossiness: namely, whether objects appear relatively dull or shiny. The results of a handful of studies suggest that people prefer shiny materials, possibly because glossiness connotes water. In one early study, for instance, Coss and Moore [35] showed adults different papers varying in their surface finishes, such as glossy, flat, sandy, and sparkly papers. Semantic differential ratings revealed that the glossier papers were rated as "wetter" and as more appealing. Meanwhile, Meert et al. [36] presented images printed on glossy or plain paper to children and adults who had to rank-order the images from most to least attractive whilst also rating attractiveness. Once again, the glossy images were consistently rated as more attractive than the plain images.

\section{What Is Wrong with Glossy/Shiny Packaging?}

It has recently been argued that visual material perception represents something of a neglected area in the field of research on packaging design $[40,44]$. Indeed, the contrast in the amount of research is especially noticeable when compared with the vast literature that has been published over the years on the topic of packaging colour (see [69,70]; see also [26,71,72]). Beyond the hue of the product packaging, some researchers have also assessed the different meanings that consumers associate with light versus dark colours in the context of food products [73-75]. For example, Mead and Richerson [75] argued that healthier products tend to be associated with more highly saturated packaging colours.

One of the most intriguing (and popular) comparisons in the marketing literature on the material properties of packaging has been between matte versus glossy versions of the same packaging (e.g., $[29,44,66,76,77])$. The research shows that people are able to detect a glossy surface appearance very rapidly $[78,79]$. Given the evolutionary appeal of shiny/glossy surfaces, one might have expected that adding a glossy finish to outer packaging ought to be appealing to consumers (cf. [32,80-82]. Furthermore, given the positive sensation transference from metallic/glossy serviceware to food (as documented earlier), one might have expected that the same beneficial effect (i.e., sensation transference) would also occur in the case of the appearance properties of the (outer) packaging of food and drink (see $[83,84]$, for the original suggestion that consumers' feelings about product packaging may carry over to influence their feelings about the product itself). It turns out, however, that many contemporary consumers have developed a crossmodal association between glossy outer packaging and greasy unhealthy foods [77]. Consequently, the literature suggests that it is not necessarily always a good idea to give one's outer packaging a glossy finish (at least not in the case of food and beverage products). In fact, a number of recent studies have highlighted how glossy packaging is nowadays associated 
(at least amongst the North American, Austrian, and Belgian participants who have been tested to date) with a number of negative attributes in the context of food and drink product packaging. Consumers appear to associate glossy packaging with those foods that are unnatural, unhealthy, and greasy [44,76,77], and with brands that are trying too hard to capture the attention of the consumer, thus lowering the perceived trustworthiness of the brand [29]. In other words, glossy packaging would often appear to carry negative connotations for consumers in the Food and Beverage (F\&B) category currently. Confusing matters somewhat, though, other recent research has highlighted how, away from the context of food and drink (i.e., in the Home and Personal Care, HPC, categories), gloss packaging is associated with increased purchase intention and willingness to pay [66].

\subsection{Outer Packaging}

According to Han [29], North American consumers perceive glossy outer packaging to be too attention capturing. Han conducted four studies (thus far reported only as a brief conference paper) in which people's impressions of a variety of product descriptions/packaging exemplars were compared in a matte versus gloss finish (see Table 1 for a summary of this and other studies that have compared matte vs. gloss product packaging). Han's results revealed that across a range of food product categories, from granola to chocolate, matte packaging was preferred to gloss. In this case, part of the reason was simply that gloss packaging made it seem as though the company/brand was trying too hard to attract their customers' attention, thus reducing the perceived trustworthiness of the brand. Han's participants had to indicate which of the two versions of the product (matte or gloss) they would choose (on a seven-point scale) and also give a trustworthiness rating to the brand. The cereal described as being presented in matte packaging (in Experiment 1) was found to be preferred over the gloss package description, mediated entirely by perceived trustworthiness. This pattern of results was replicated in a second experiment now involving graphical representations of product packaging (of chocolate and granola). That said, Han [29], Experiment 3, went on to demonstrate that outside the context of food and drink, a glossy finish was deemed as being less unacceptable for a premium brand, such as Chanel, than it was for a generic (fake) brand. In other words, the tendency to consider glossy packaging to be less trustworthy was reduced for a high-quality or premium brand (at least outside the context of food and drink). In Han's fourth experiment, the participants rated glossy packaging as more immediately attention capturing, whereas there was a borderline-significant suggestion for the participants to think that matte packaging held their attention for longer. (It would, however, be desirable to have objective measures of attentional capture to back-up these subjective ratings) Once again, glossiness led to lower levels of trustworthiness, based on attempts to capture their attention being seen as a marketing tactic by the participants. 
Table 1. Summary of studies of glossy vs. matte outer product packaging.

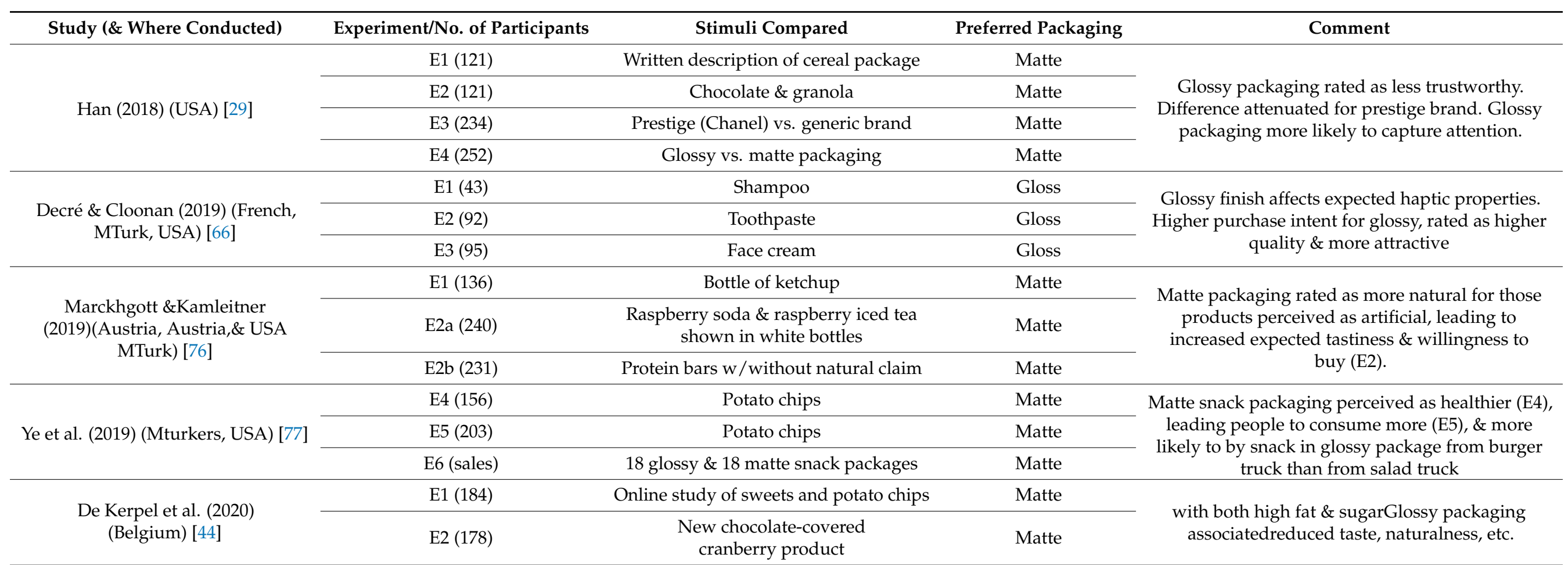


It has been reported that matte packaging can help to increase the perceived naturalness of food products [76]. The latter researchers conducted a series of three studies in which their participants were shown product packaging of a range of everyday food products, including an unlabelled red plastic ketchup bottle (Experiment 1), raspberry soda and raspberry iced tea shown in labelled white bottles (Experiment 2a), and protein bar labels either with or without a natural product claim (Experiment 2b). The participants rated perceived naturalness, expected tastiness, and quality of the products on seven-point scales, as well as rating their purchase intent (Experiment 2). Experiments 1 and 2a were conducted in a mock-up Point-of-Sale in the lab in Austria (with multiple products), whereas Experiment $2 \mathrm{~b}$ was conducted to imitate online product inspection showing only a single product at a time that the participant (USA MTurkers) could zoom in on. Experiment 1 also compared looking versus looking and handling the product packaging, though this factor did not influence the pattern of results obtained. The matte version of the packaging was rated as looking more natural when the product itself was considered fairly artificial (e.g., tomato ketchup, raspberry soda, and the protein bar without an explicit natural claim). The matte-natural association led on to follow-on effects (i.e., mediated the effects) on expected tastiness (all experiments) and increased willingness to purchase (Experiment 2).

Ye et al. [77] conducted a series of six studies showing firstly (based on audits of six North American retail stores) that unhealthy foods like potato chips tends to be come in glossy packaging whereas healthier snacks, like crackers, tend to be sold in matte packaging (Experiment 1). Of the 2656 packages classified, the majority of potato chips on shelf were in glossy packaging $(76.8 \%)$ whereas only a minority of crackers were packaged in glossy packaging (4.5\%). In Experiment 2, a new group of participants were asked explicitly about their expectations concerning matte and gloss packaging. As might have been expected, participants expected less healthy/more greasy snacks to come in glossy packaging. Thereafter, these researchers used a simplified version of the Implicit Association Test to demonstrate that North American consumers appear to have internalised this crossmodal association (or correspondence; Experiment 3). Experiment 4 demonstrated that those snack foods with glossy (matte) surfaces were inferred to be less (more) healthy. In Experiment 5, the researchers demonstrated that participants both poured less potato chips from a gloss bag than from a matte bag when instructed to serve $50 \mathrm{~g}$ (10.21 g vs. $11.77 \mathrm{~g}$ ). Thereafter, they were also shown to consume slightly (but significantly) less when the potato chips came from a matte bag (Experiment 5). Finally, in Experiment 6, Ye et al. demonstrated that people were more likely to buy snack products (potato chips, corn chips, or popcorn) in glossy packaging from a burger truck (73\% of sales) than from a salad truck ( $34 \%$ of sales being glossy). The suggestion was that those choosing to visit the burger truck were presumably focused more on taste than those who chose the salad truck - they were motivated to engage in tasty rather than healthful eating.

Ye et al. [77] argue for learned associations between unhealthy (i.e., greasy) foods and shiny packaging as the cause of the effects that they observed (so, in other words, the suggestion is that consumers internalise the natural statistic of the marketplace): namely, that greasy (and unhealthy) foods tend to be sold in glossy (rather than matte) packages. (It should be noted though that, at least in Spain, crisps (potato chips) that are sold in matte packaging tend to be more expensive than those sold in metallised glossy packaging [85].) However, as De Kerpel et al. [44] have pointed out subsequently, sugary products are often sold in glossy packaging, and consumers appear to have internalised the latter association too.

The influence of packaging glossiness on the perception of food products was recently investigated in a couple of studies reported by De Kerpel et al. [44]. These researchers first conducted an online study in which they probed participants about their expectations/beliefs concerning the taste qualities that they associated with food product packaging (for sweets and potato chips) having a glossy (vs. matte) finish. The results revealed that participants expected both products to come in glossy packaging. This questionnaire was then followed up by an in-store experiment in which shoppers at a tasting table in 
Belgium were invited to sample a new chocolate cranberry product from packaging that had either been given a glossy or a matte finish. De Kerpel et al. [44] also varied the packaging format (bag or can). Importantly, each participant rated only one of the four packaging formats, thus ensuring that undue attention was not focused on the finish of the packaging (i.e., matte vs. gloss). The participants were first asked about their expectations on handling the packaging. Seven-point semantic differential scales were used to assess expected fat content, expected sugar content of the new chocolate product. The participants were also asked about the expected healthiness, quality, and expensiveness of the product prior to tasting. The participants then got to sample the chocolates and rate their taste experience (tastes good, tastes appetising).

The results revealed that the expected fat content of the chocolates was higher, while the expected sugar content was lower, for the glossy as compared to the matte version of the packaging. Overall, matte packaging led to higher expected product health, expensiveness, and quality, while, at the same time, also enhancing rated taste experience on sampling the chocolates. Intriguingly, however, and in contrast to Marckhgott and Kamleitner [76], the finish of the packaging had no influence on the expected naturalness of the products, perhaps because the products were not perceived as artificial in the first place (though this is nothing more than a post hoc explanation.

De Kerpel et al.'s [44] research, like that of Ye et al. [77], therefore suggests that people associate glossy food packaging with those products having a higher fat content. An inference (or derived belief) that follows on from this is that a food product that is presented in a glossy package will be perceived as less healthy, less tasty, lower in quality, and cheaper. Thus, taken together, while the results of De Kerpel et al.'s [44] study demonstrate that Belgian consumers associate glossy product packaging with fat in food and with those products that are sugary, the glossy association with greasiness appears to dominate product perception, thus suggesting that the evolutionary account of many fats being glossy provides a better explanation for the data than simply learned associations $[44,66,77]$ (There are, though, a number of interesting follow-up questions here concerning the differences, if any, between saturated and unsaturated fats (think avocado), and their visual associations (see also [44]).

At the same time, Decré and Cloonan [66] came to a somewhat different conclusion regarding people's perception of glossy packaging based on a series of three betweenparticipants experiments showing that manipulating packaging (glossy versus matte) not only influenced people's perception of the haptic textural properties of packaging but also influenced their ratings of perceived product quality and attractiveness too. Giving the packaging of HPC products (shampoo, toothpaste, and face cream) a glossy finish led to increased ratings of product attractiveness, liking/beauty, and quality. This also had a knock-on effect on behavioural intentions, namely purchase intent but not on willingness to pay. It is striking how this is the only one of the five studies reviewed in Table 1 to find that glossy packaging enhanced product perception; it is also the only study to have been conducted entirely outside of the F\&B space.

\subsection{Limitations of the Research on Glossy vs. Matte Packaging Cues}

One of the problems, or limitations, with those studies that have compared matte versus gloss packaging is that the two packaging formats tend to be assessed in isolation. Furthermore, there is also a concern that having participants directly compare matte versus gloss versions of the same packaging may draw the participants' attention to this particular aspect of the visual appearance (since it is the only one that changes) in a way that is normally not be the case (see [46] for a similar criticism levelled at those studies that have manipulated whether pictures have a glossy vs. matte surface). Important in this regard, therefore, De Kerpel et al. [44], Experiment 2, conducted one of the only betweenparticipants studies of gloss versus matte packaging in the ecologically-valid context of a tasting table in a store (meaning that each participant only experienced one example of product packaging). That said, Decré and Cloonan's [27] studies in the HPC category were 
also conducted on a between-participants basis. This is obviously going to be more realistic given that in the marketplace, most products are typically only displayed in one finish (i.e., either matte or gloss).

Most commercial food and beverage products need to compete for the consumer's visual attention in the food aisle (see also [44], who highlight much the same point), and increasingly online too [86-89]. As such, one might want to question just how informative the findings of those studies in which packaging exemplars are presented in isolation actually are (cf. [25]). It would certainly be interesting in future research to investigate whether glossy objects (specifically food and beverage packages) pop-out from realistic shelves of products in the context of visual search [90-93].

\subsection{Inner Packaging}

The appearance properties of the outer packaging of food and beverage products are normally only one element in the consumers' total packaging experience. The visual material properties of inner packaging materials are potentially also important too [70,94,95]. Relevant here, in his history of consumer food packaging in the West (in truth, primarily North America), Hine has highlighted the longstanding appeal and incorporation of shiny metallic elements in the inner packaging of many food and beverage products [96]. Indeed, Nestlé were criticised in some quarters back in 2001 when they switched their iconic foil inner sleeve (and paper outer) for their KitKat after 65 years for a single flow-wrap plastic foil packaging [97]. Part of the reason for the change may have been growing concerns about the sustainability of different packaging formats, given that nowadays metallic packaging is not universally popular, due to concerns about sustainability, etc. [70,98].

There is a growing recognition that the visual appearance of inner packaging, and even the appearance of the product against inner surface of the inner packaging, e.g., as when consuming crisps (potato chips) direct from the bag, can (and should) be considered as an important part of the total multisensory product experience. It may be that a glossy or coloured inner packaging is interpreted rather differently by the consumer than exactly the same visual appearance property when displayed as outer packaging [99]. That said, there is undoubtedly a shortage of research on the impact of inner packaging colour/finish which, note, is likely to be especially important for those food products that are normally consumed direct from the packaging, such as is often the case for crisps/potato chips [100]. The main point to stress here is that when considering packaging recommendations concerning the use of matte versus gloss packaging, the answer may depend on whether one is considering outer vs. inner packaging.

\section{Conclusions}

As this review of the literature has hopefully made clear, adding a glossy/shiny finish to one's packaging (be it outer or inner product packaging) is not always a good idea in terms of managing/enhancing the consumer's expectations/associations [101]. In part, this is because of growing concerns about sustainability in the case of metallic inner packaging [98,102]. However, researchers have also highlighted the association that has been internalised by consumers that greasy foods tend to come in glossy packaging [77]. According to Han [29], adding gloss to one's packaging can make it seem like a brand (especially one that is not especially well established) is trying too hard to capture the consumers' attention, and for those aiming to convey the notion of a natural product, matte packaging seems better [76]. De Kerpel et al. [44] have argued for an evolutionary account linking glossiness with fattiness, rather than the learned associations account, given that consumers have also internalised the association between sugary products and glossy packaging.

At the same time, it is important to stress the fact that the majority of research in this area has been conducted in a small number of Western markets (see Table 1). This obviously leaves open the possibility that consumers in other parts of the world may have internalised somewhat different associations/conventions with such unbranded visual appearance cues 
as represented by gloss/matte packaging. Indeed, given that cross-cultural differences in the meaning of packaging colour have been well documented, it would perhaps be surprising were the same not also found to be true of metallic, shiny/glossy finishes on packaging. Furthermore, looking to the future, it might be beneficial to adopt more implicit experimental approaches to the study of packaging design in the case of food and beverage products, rather than those that have relied on explicit subjective judgments $([103,104]$, for a couple of implicit testing paradigms that would be appropriate to assess the associations and appeal of food and beverage packaging; and see Ye et al. [77], Experiment 3).

Finally, when considering the meaning of visual appearance cues in the case of food and beverage packaging, it is important to stress the important differences that may sometimes be present when the same packaging material is incorporated into inner versus outer packaging. That said, to date, the majority of the research has tended to focus on the different association/meaning that might be associated with outer packaging. There may also be some interesting/salient individual differences to be aware of in this space too (cf. [105-107]).

It will also be interesting in future research to examine whether the meaning/associations of a glossy versus matter surface finish might differ depending on the product contained within. It would be interesting to investigate whether a glossy finish might prime associations with fat in greasy products such as potato chips, while perhaps connoting freshness in the case of the packaging of seafood (cf. [38,77]). Additionally, should a glossy finish be added to the packaging of bottled (or nowadays canned) water then perhaps the link between glossy and the presence of water will be preferentially primed instead. Were such a suggestion to be validated by future research, then it might mean that there are no absolute associations with glossy packaging. Rather, the meaning is constrained both by the category of (food) product and perhaps by the country in which the product is sold. The same is presumably also true in the case of shiny metallic packaging features as well (cf. [108]).

In future research, it will be important to look at actual sales, rather than just willingness to pay (cf. [44,109]). Note here only how Ye et al. [77], Experiment 6, is the only study published to date that has actually assessed sales of matte vs. gloss packaging. Ultimately, based on the available research, the benefit of matte over gloss finish would appear to be reduced for those foods that are already perceived as natural [76], and possibly also for those brands that are perceived as premium [29]. Meanwhile, outside the F\&B category (i.e., in HPC), different rules may apply [66]. As Ye et al. [77] suggest, it would also be interesting to know whether automobiles with a shinier paint finish are also perceived as faster, and more luxurious [110].

Funding: This research received no external funding.

Conflicts of Interest: The author declares no conflict of interest.

\section{References}

1. Aldersey-Williams, H. Periodic Tales: The Curious Lives of the Elements; Viking: London, UK, 2011.

2. Feldman, C.; Jones, P. Simplicity and performance in Roman agrarian foods. In Handbook of Eating and Drinking; Meiselman, H., Ed.; Springer: Cham, Switzerland, 2020; pp. 93-111. [CrossRef]

3. Tanizaki, J. Praise of Shadows; Trans, B., Harper, T.J., Seidenstickker, E.G., Eds.; Vintage Books: London, UK, 2001.

4. Woolgar, C. Medieval food and colour. J. Mediev. Hist. 2018, 44, 1-20. [CrossRef]

5. Ariely, D. Predictably Irrational: The Hidden Forces that Shape Our Decisions; Harper Collins Publishers: London, UK, 2008.

6. Carvalho, F.M.; Spence, C. Do metallic-coated cups affect the perception of specialty coffees? An exploratory study. Int. J. Gastron. Food Sci. 2021, 23, 100285. [CrossRef]

7. Spence, C.; Piqueras-Fiszman, B. The Perfect Meal: The Multisensory Science of Food and Dining; Wiley-Blackwell: Oxford, UK, 2014.

8. Apicius. Cooking and Dining in Imperial Rome; University of Chicago Press: Chicago, IL, USA, 1936.

9. Arce, H. Groucho; Putnum: New York, NY, USA, 1979.

10. Crumpacker, B. The Sex Life of Food: When Body and Soul Meet to Eat; Thomas Dunne Books: New York, NY, USA, 2006.

11. Berghaus, G. The futurist banquet: Nouvelle Cuisine or performance art? New Theatre Quart. 2001, 17, 3-17. [CrossRef]

12. Spence, C.; Carvalho, F. Metallic: A bivalent, amodal material property? i-Percept 2021, submitted. 
13. Matsumoto, T.; Fukuda, K.; Uchikawa, K. Appearance of gold, silver and copper colors of glossy object surface. Int. J. Affect. Engin. 2016, 15, 239-247. [CrossRef]

14. Liu, J.; Lughofer, E.; Zeng, X. Aesthetic perception of visual textures: A holistic exploration using texture analysis, psychological experiment, and perception modeling. Front. Comput. Neurosci. 2015, 9, 134. [CrossRef]

15. Thumfart, S.; Jacobs, R.H.; Lughofer, E.; Eitzinger, C.; Cornelissen, F.W.; Groissboeck, W.; Richter, R. Modeling human aesthetic perception of visual textures. ACM Trans. Appl. Percept. 2008, 8, 1-29. [CrossRef]

16. Yanagisawa, H.; Yuki, N. Deviations of visual expectation from somatosensory experience in emotional quality: Effects of surface characteristic in context of "lifting object". In ASME 2011 International Design Engineering Technical Conferences and Computers and Information in Engineering Conference; American Society of Mechanical Engineers Digital Collection: New York, NY, USA, 2011; pp. 825-832.

17. Zhou, X.; Wan, X.; Mu, B.; Du, D.; Spence, C. Crossmodal associations and subjective ratings of Asian noodles and the impact of the receptacle. Food Qual. Pref. 2015, 41, 141-150. [CrossRef]

18. Andrews, A.C. The Roman craze for Surmullets. Class. Wkly. 1949, 42, 186-188. [CrossRef]

19. Kirmani, A.; Zeithaml, V. Advertising, perceived quality, and brand image. In Brand Equity E Advertising: Advertising's Role in Building Strong Brands; Aaker, D.A., Biel, A.L., Eds.; Lawrence Erlbaum Associates: Hillsdale, NJ, USA, $1993 ;$ pp. $143-162$.

20. Aslam, M.M. Are you selling the right colour? A cross-cultural review of colour as a marketing cue. J. Mark. Comm. 2006, 12, 15-30. [CrossRef]

21. Wheatley, J. Putting colour into marketing. Marketing 1973, 67, 24-29.

22. Burton, D. Cross-Cultural Marketing: Theory, Practice and Relevance; Routledge: New York, NY, USA, 2008.

23. Heide, M.; Olsen, S.O. Influence of packaging attributes on consumer evaluation of fresh cod. Food Qual. Pref. 2017, 60, 9-18. [CrossRef]

24. Gangjee, D.S. Paying the Price for Admission: Non-Traditional Marks Across Registration and Enforcement; Oxford University Press: Oxford, UK, 2018.

25. Labrecque, L.I.; Milne, G.R. To be or not to be different: Exploration of norms and benefits of color differentiation in the marketplace. Market. Lett. 2013, 24, 165-176. [CrossRef]

26. Sperdea, N.M.; Criveanu, I. Marketing in colors. Rev. Econ. 2014, 66, 91-99.

27. Heine, K.; Phan, M.; Atwal, G. Authenticity and prestige: What luxury brands could learn from the wine industry? Lux. Res. J. 2016, 1, 177-190. [CrossRef]

28. Pelet, J.E.; Durrieu, F.; Lick, E. Label design of wines sold online: Effects of perceived authenticity on purchase intentions. J. Retail. Cons. Serv. 2020, 55, 102087. [CrossRef]

29. Han, Y. All that glitters is not gold: Packaging glossiness, attention, and trustworthiness. In Advances in Consumer Research Volume 11; Geuens, M., Pandelaere, M., Pham, M.T., Vermeir, I., Eds.; Association for Consumer Research: Duluth, MN, USA, 2018; pp. 81-82. Available online: https://www.acrwebsite.org/volumes/1700142/volumes/v11e/E-11 (accessed on 27 April 2021).

30. Komatsu, H.; Goda, N. Neural mechanisms of material perception: Quest on Shitsukan. Neuroscience 2018, 392, 329-347. [CrossRef]

31. LaBonte, D.A. Shiny Objects Marketing: Using Simple Human Instincts to Make Your Brand Irresistible; John Wiley \& Sons: Hoboken, NJ, USA, 2009.

32. Silvia, P.J.; Christensen, A.P.; Cotter, K.N.; Jackson, T.A.; Galyean, C.B.; McCroskey, T.J.; Rasheed, A.Z. Do people have a thing for bling? Examining aesthetic preferences for shiny objects. Empirical Stud. Arts 2018, 36, 101-113. [CrossRef]

33. Shephard, T.V.; Lea, S.E.G.; Hempel de Ibarra, N. 'The thieving magpie'? No evidence for attraction to shiny objects. Anim. Cogn. 2015, 18, 393-397. [CrossRef]

34. Coss, R.G. The role of evolved perceptual biases in art and design. In Evolutionary Aesthetics; Voland, E., Grammar, K., Eds.; Springer: Berlin, Germany, 2003; pp. 69-130.

35. Coss, R.G.; Moore, M. All that glistens: Water connotations in surface finishes. Ecol. Psych. 1990, 2, 367-380. [CrossRef]

36. Meert, K.; Pandelaere, M.; Patrick, V.M. Taking a shine to it: How the preference for glossy stems from an innate need for water. J. Cons. Psychol. 2014, 24, 195-206. [CrossRef]

37. Sawayama, M.; Adelson, E.H.; Nishida, S.Y. Visual wetness perception based on image color statistics. J. Vis. 2017, 17, 1-24. [CrossRef]

38. Murakoshi, T.; Masuda, T.; Utsumi, K.; Tsubota, K.; Wada, Y. Glossiness and perishable food quality: Visual freshness judgment of fish eyes based on luminance distribution. PLoS ONE 2013, 8, e58994. [CrossRef]

39. Arce-Lopera, C.; Masuda, T.; Kimura, A.; Wada, Y.; Okajima, K. Model of vegetable freshness perception using luminance cues. Food Qual. Pref. 2015, 40, 279-286. [CrossRef]

40. Di Cicco, F.; Zhao, Y.; Wijntjes, M.W.A.; Pont, S.C.; Schifferstein, H.N.J. A juicy orange makes for a tastier juice: The neglected role of visual material perception in packaging design. Food Qual. Pref. 2021, 88, 104086. [CrossRef]

41. Harrar, V.; Toepel, U.; Murray, M.; Spence, C. Food's visually-perceived fat content affects discrimination speed in an orthogonal spatial task. Exp. Brain Res. 2011, 214, 351-356. [CrossRef] [PubMed]

42. Motoki, K.; Saito, T.; Suzuki, S.; Sugiura, M. Evaluation of energy density and macronutrients after extremely brief time exposure. Appetite 2021, 162, 105143. [CrossRef] 
43. Toepel, U.; Knebel, J.; Hudry, J.; Lecoutre, J.; Murray, M. The brain tracks the energetic value in food images. Neuroimage 2009, 44, 967-974. [CrossRef]

44. De Kerpel, L.; Volles, B.K.; Van Kerckhove, A. Fats are glossy, but does glossiness imply fatness? The influence of packaging glossiness on food perceptions. Foods 2020, 9, 90. [CrossRef]

45. Saad, G.; Gill, T. Applications of evolutionary psychology in marketing. Psych. Mark. 2000, 17, 1005-1034. [CrossRef]

46. Silvia, P.J.; Christensen, A.P.; Cotter, K.N. Aesthetic Preference for Glossy Materials: A Replication and Extension. PsyArXiv 2020, unpublished manuscript. [CrossRef]

47. Christensen, A.P.; Cotter, K.N.; Silvia, P.J. Reopening openness to experience: A network analysis of four openness to experience inventories. J. Pers. Assess. 2019, 106, 574-588. [CrossRef]

48. Chadwick, A.C.; Kentridge, R.W. The perception of gloss: A review. Vis. Res. 2015, 109, 221-235. [CrossRef]

49. Ferwerda, J.A.; Pellacini, F.; Greenberg, D.P. A psychophysically based model of surface gloss perception. In Human Vision and Electronic Imaging VI; Rogowitz, B.E., Pappas, T.N., Eds.; SPI: Bellingham, WA, USA, 2001; pp. 291-301.

50. Fleming, R.W. Human perception: Visual heuristics in the perception of glossiness. Curr. Biol. 2012, 22, R865-R866. [CrossRef]

51. Ged, G.; Obein, G.; Silvestri, Z. Recognizing real materials from their glossy appearance. J. Vis. 2010, 10, 1-17. [CrossRef] [PubMed]

52. Hunter, R.S. Methods of determining gloss. J. Res. Nat. Bur. Stand. 1937, 18, 19-39. [CrossRef]

53. Landy, M.S. Visual perception: A gloss on surface properties. Nature 2007, 447, 158-159. [CrossRef]

54. Wills, J.; Agarwal, S.; Kriegman, D.; Belongie, S. Toward a perceptual space for gloss. ACM Trans. Graph. 2009, 28, 1-15. [CrossRef]

55. Nayar, S.K.; Oren, M. Visual appearance of matte surfaces. Science 1995, 267, 1153-1156. [CrossRef]

56. Chadwick, A.C.; Cox, G.; Smithson, H.E.; Kentridge, R.W. Beyond scattering and absorption: Perceptual unmixing of translucent liquids. J. Vis. 2018, 18, 1-15. [CrossRef]

57. Di Cicco, F.; Wijntjes, M.W.A.; Pont, S.C. If Painters Give You Lemons, Squeeze the Knowledge Out of Them. A Study on the Visual Perception of the Translucent and Juicy Appearance of Citrus Fruits in Paintings. J. Vis. 2020, 20, 12. [CrossRef]

58. Anderson, B.L. Visual perception of materials and surfaces. Curr. Biol. 2011, 21, R978-R983. [CrossRef] [PubMed]

59. Marlow, P.J.; Anderson, B.L. Generative constraints on image cues for perceived gloss. J. Vis. 2013, 13, 1-23. [CrossRef] [PubMed]

60. Tanaka, M.; Horiuchi, T. Investigating perceptual qualities of static surface appearance using real materials and displayed images. Vis. Res. 2015, 115, 246-258. [CrossRef] [PubMed]

61. Ueda, J.; Spence, C.; Okajima, K. Effects of varying the standard deviation of the luminance on the appearance of food, flavour expectations, and taste/flavour perception. Sci. Rep. 2020, 10, 16175. [CrossRef]

62. Anderson, B.L.; Kim, J. Image statistics do not explain the perception of gloss and lightness. J. Vis. 2009, 9, 10-17. [CrossRef]

63. Ingvarsdóttir, K.Ó.; Balkenius, C. The visual perception of material properties affects motor planning in prehension: An analysis of temporal and spatial components of lifting cups. Front. Psychol. 2020, 11, 215. [CrossRef]

64. Adams, W.J.; Kerrigan, I.S.; Graf, E.W. Touch influences perceived gloss. Sci. Rep. 2016, 6, 21866. [CrossRef]

65. Lichtenauer, M.S.; Schuetz, P.; Zolliker, P. Interaction improves perception of gloss. J. Vis. 2013, 13, 1-13. [CrossRef]

66. Decré, G.B.; Cloonan, C. A touch of gloss: Haptic perception of packaging and consumers' reactions. J. Prod. Brand Manag. 2019, 28, 117-132. [CrossRef]

67. Cloonan, C.; Briand-Decré, G. The cross-modal effects of packaging glossiness on haptic perception. In Asia-Pacific-Advances in Consumer Research Proceedings; Wan, E.W., Zhang, M., Eds.; Association for Consumer Research: Hong Kong, China, 2015; pp. 124-125.

68. Fujisaki, W.; Tokita, M.; Kariya, K. Perception of the material properties of wood based on vision, audition, and touch. Vis. Res. 2015, 109, 185-200. [CrossRef]

69. Spence, C.; Velasco, C. Packaging colour and its multiple roles. In Multisensory Packaging: Designing New Product Experiences; Velasco, C., Spence, C., Eds.; Palgrave MacMillan: Cham, Switzerland, 2019; pp. 21-48.

70. Velasco, C.; Spence, C. Multisensory packaging: Designing New Product Experiences; Palgrave MacMillan: Cham, Switzerland, 2019. [CrossRef]

71. Huang, L.; Lu, J. Eat with your eyes: Package color influences the expectation of food taste and healthiness moderated by external eating. Market. Manage. J. 2015, 25, 71-87.

72. da Rosa, V.M.; Spence, C.; Tonetto, L.M. Influences of visual attributes of food packaging on consumer preference and associations with taste and healthiness. Int. J. Cons. Stud. 2019, 43, 210-217. [CrossRef]

73. Mai, R.; Symmank, C.; Seeberg-Elverfeldt, B. Light and pale colors in food packaging: When does this package cue signal superior healthiness or inferior tastiness? J. Retail. 2016, 92, 426-444. [CrossRef]

74. Tijssen, I.; Zandstra, E.H.; de Graaf, C.; Jager, G. Why a 'light’ product package should not be light blue: Effects of package colour on perceived healthiness and attractiveness of sugar- and fat-reduced products. Food Qual. Pref. 2017, 59, 46-58. [CrossRef]

75. Mead, J.A.; Richerson, R. Package color saturation and food healthfulness perceptions. J. Bus. Res. 2018, 82, 10-18. [CrossRef]

76. Marckhgott, E.; Kamleitner, B. Matte matters: When matte packaging increases perceptions of food naturalness. Mark. Lett. 2019, 30, 167-178. [CrossRef]

77. Ye, N.; Morrin, M.; Kampfer, K. From glossy to greasy: The impact of learned associations on perceptions of food healthfulness. $J$. Consum. Psych. 2019, 30, 96-124. [CrossRef] 
78. Nagai, T.; Matsushima, T.; Koida, K.; Tani, Y.; Kitazaki, M.; Nakauchi, S. Temporal properties of material categorization and material rating: Visual vs. non-visual material features. Vis. Res. 2015, 115, 259-270. [CrossRef] [PubMed]

79. Sharan, L.; Rosenholtz, R.; Adelson, E. Material perception: What can you see in a brief glance? J. Vis. 2009, 9, 1-24. [CrossRef]

80. Ampuero, O.; Vila, N. Consumer perceptions of product packaging. J. Cons. Mark. 2006, 23, 100-112. [CrossRef]

81. Ashby, M.; Johnson, K. Materials and Design: The Art and Science of Material Selection in Product Design; Elsevier: Oxford, UK, 2002.

82. Patrick, V.M. Everyday consumer aesthetics. Curr. Op. Psych. 2016, 10, 60-64. [CrossRef]

83. Cheskin, L. How to Predict What People Will Buy; Liveright: New York, NY, USA, 1957.

84. Cheskin, L. Marketing Success: How to Achieve It; Cahners Books: Boston, MA, USA, 1972.

85. Rebollar, R.; Gil, I.; Lidón, I.; Martín, J.; Fernández, M.J.; Rivera, S. How material, visual and verbal cues on packaging influence consumer expectations and willingness to buy: The case of crisps (potato chips) in Spain. Food Res. Int. 2017, 99, 239-246. [CrossRef] [PubMed]

86. Benn, Y.; Webb, T.L.; Chang, B.P.; Reidy, J. What information do consumers consider, and how do they look for it, when shopping for groceries online? Appetite 2015, 89, 265-273. [CrossRef] [PubMed]

87. Grewal, D.; Roggeveen, A.L.; Nordfält, J. The future of retailing. J. Retail. 2017, 93, 1-6. [CrossRef]

88. Kahn, B.E. Using visual design to improve customer perceptions of online assortments. J. Retail. 2017, 93, 29-42. [CrossRef]

89. Knoeferle, K.; Knoeferle, P.; Velasco, C.; Spence, C. Multisensory brand search: How the meaning of sounds guides consumers' visual attention. J. Exp. Psychol. Appl. 2016, 22, 196-210. [CrossRef]

90. Maljkovic, V.; Nakayama, K. Priming of pop-out: I. Role of features. Mem. Cogn. 1994, 22, 657-672. [CrossRef]

91. Treisman, A.M.; Gelade, G. A feature-integration theory of attention. Cogn. Psych. 1980, 12, 97-136. [CrossRef]

92. Treisman, A.; Gormican, S. Feature analysis in early vision: Evidence from search asymmetries. Psychol. Rev. 1988, 95, 15-48. [CrossRef]

93. Wolfe, J.M.; Franzel, S.L. Binocularity and visual search. Percept. Psychophys. 1988, 44, 81-93. [CrossRef]

94. Krishna, A.; Cian, L.; Aydinoğlu, N.Z. Sensory aspects of package design. J. Retail. 2017, 93, 43-54. [CrossRef]

95. van Esch, P.; Heller, J.; Northey, G. The effects of inner packaging color on the desirability of food. J. Retail. Consum. Serv. 2019, 50, 94-102. [CrossRef]

96. Hine, T. The Total Package: The Ssecret History and Hidden Meanings of Boxes, Bottles, Cans, and Other Persuasive Containers; Little Brown: New York, NY, USA, 1995.

97. Anon. KitKat Breaks with Past. The Guardian, 7 June 2001. Available online: https://www.theguardian.com/uk/2001/jun/07/1 (accessed on 23 February 2021).

98. Steenis, N.D.; Herpen, E.; van der Lans, I.A.; Lighthart, T.N.; van Trijp, H.C.M. Consumer response to packaging design: The role of packaging materials and graphics in sustainability perceptions and product evaluations. J. Clean. Prod. 2017, 162, 286-298. [CrossRef]

99. Spence, C. Background colour \& its impact on food perception \& behaviour. Food Qual. Pref. 2018, 68, 156-166.

100. Spence, C.; Shankar, M.U.; Blumenthal, H. 'Sound bites': Auditory contributions to the perception and consumption of food and drink. In Art and The Senses; Bacci, F., Melcher, D., Eds.; Oxford University Press: Oxford, UK, 2011; pp. $207-238$.

101. Piqueras-Fiszman, B.; Spence, C. Sensory expectations based on product-extrinsic food cues: An interdisciplinary review of the empirical evidence and theoretical accounts. Food Qual. Pref. 2015, 40, 165-179. [CrossRef]

102. Magnier, L.; Schoormans, J.; Mugge, R. Judging a product by its cover: Packaging sustainability and perceptions of quality in food products. Food Qual. Pref. 2016, 53, 132-142. [CrossRef]

103. Parise, C.V.; Spence, C. Assessing the associations between brand packaging and brand attributes using an indirect performance measure. Food Qual. Pref. 2012, 24, 17-23. [CrossRef]

104. Piqueras-Fiszman, B.; Kraus, A.; Spence, C. "Yummy" versus "yucky"! Explicit and implicit approach-avoidance motivations toward appealing and disgusting foods in normal eaters. Appetite 2014, 78, 193-202. [CrossRef] [PubMed]

105. Haasova, S.; Florack, A. Practicing the (un)healthy = tasty intuition: Toward an ecological view of the relationship between health and taste in consumer judgments. Food Qual. Pref. 2019, 75, 39-53. [CrossRef]

106. Raghunathan, R.; Naylor, R.W.; Hoyer, W.D. The unhealthy = tasty intuition and its effects on taste inferences, enjoyment, and choice of food products. J. Mark. 2006, 70, 170-184. [CrossRef]

107. Werle, C.O.C.; Trendel, O.; Ardito, G. Unhealthy food is not tastier for everybody: The "healthy = tasty" French intuition. Food Qual. Pref. 2013, 28, 116-121. [CrossRef]

108. Labrecque, L.L.; Patrick, V.M.; Milne, G.R. The marketer's prismatic palette: A review of color research and future directions. Psychol. Mark. 2013, 30, 187-202. [CrossRef]

109. Milosavljevic, M.; Navalpakkam, V.; Koch, C.; Rangel, A. Relative visual saliency differences induce sizable bias in consumer choice. J. Cons. Psychol. 2012, 22, 67-74. [CrossRef]

110. Spence, C. Shitsukan-The multisensory perception of quality. Multisens. Res. 2020, 33, 737-775. [CrossRef] [PubMed] 